\title{
Decolorization of C. I. Reactive Orange 4 and Textile Effluents by Electrochemical Oxidation Technique using Silver-Carbon Composite Electrode
}

\author{
Norazzizi Nordin, ${ }^{1}$ Siti Fathrita Mohd Amir, ${ }^{1}$ Muhammad Rahimi Yusop ${ }^{1}$ \\ and Mohamed Rozali Othman ${ }^{1,2, *}$ \\ ${ }^{1}$ School of Chemical Sciences and Food Technology, Faculty of Science and Technology, Universiti Kebangsaan Malaysia, \\ 43600 UKM Bangi, Selangor, Malaysia. \\ ${ }^{2}$ Centre for Water Research \& Analysis (ALIR), Faculty of Science and Technology, Universiti Kebangsaan Malaysia, \\ 43600 UKM Bangi, Selangor, Malaysia. \\ * Corresponding author: E-mail: rozali@ukm.edu.my \\ Tel.: (+60 389213342$)$
}

Received: 04-12-2014

\begin{abstract}
In this study, the electrochemical oxidation of C. I. Reactive Orange 4 (RO4) on a silver-carbon composite (AgC-PVC) electrode was studied using the cyclic voltammetry, potential liner V, and electrolysis methods. The AgC-PVC electrode was used as the working electrode in the electrochemical measurement of $\mathrm{RO} 4$ in the presence of $\mathrm{NaCl}$ as a supporting electrolyte. The UV-Vis spectra of RO4 after the electrochemical oxidation showed the complete decolorization of the solution. The electrolysis products were characterized using FTIR and GC-MS. The results showed that in the presence of $\mathrm{OCl}^{-}$as an active oxidant, RO4 molecules are broken down into several lower-molecular-weight molecules by the electrochemical technique. The electrode used was also able to reduce the COD, $\mathrm{BOD}_{5}$ and surfactant contents in the textile effluents using a pilot scale reactor. This proved that the prepared AgC-PVC electrode was beneficial for removing both the color and other pollutants from textile effluents.
\end{abstract}

Keywords: Decolorization; electrochemical oxidation; composite electrode; textile effluents; C. I. Reactive Orange 4

\section{Introduction}

Dyes are a major problem in textile effluent management because dye colors are visible with the naked eye even in small quantities $\left(<1 \mathrm{mg} \mathrm{L}^{-1}\right)$. Only $60-90 \%$ of the dyes used in the textile industries is fixed to textile fibers, with the remaining $10-40 \%$ is discharged as effluent. ${ }^{1}$ Azo dyes are the most widely used dyes in the textile industry. ${ }^{2}$ These dyes contain the azo chromophore group $(-\mathrm{N}=\mathrm{N}-)$, along with an auxochrome such as -OH or $-\mathrm{SO}_{3} .{ }^{3}$ Reactive dyes are one example of an azo dyes that contains the azo group in its molecular structure. A special feature of reactive dyes are the formation of covalent bonds between the dyes and textile fibers. ${ }^{4}$ Because of the existence of the azo group in their structures, the presence of reactive dyes in the environment has a negative impact on the environment and human health. ${ }^{5}$ Therefore, the decolorization of textile industry effluent is very important before releasing it to the environment.

The electrochemical oxidation technique has gained attention in recent years for textile industrial effluent treatment because of its efficiency in removing organic and inorganic pollutants from effluents. ${ }^{3}$ In addition, no additional chemical is required for electrochemical oxidation, because the electron is the main reagent in the electrochemical reaction. ${ }^{2}$ The non-biodegradable molecules in reactive dyes can be broken into smaller molecules and easily removed using this electrochemical oxidation technique. ${ }^{6}$ The working electrode plays an important role in electrochemical studies because it acts as a site for electrooxidation and electrocatalytic reactions. Therefore, the selection of electrode materials play an important role in obtaining an electrode with the highest efficiencies for an electrochemical reaction and electrocatalytic reactivity. ${ }^{7}$ Among the 
electrodes that have been used in the decolorization study of synthetic dyes and textile industry effluents are $\mathrm{Pt}^{4,8,9}$ boron-doped diamond (BDD), ${ }^{3,10,11}$ dimensionally stable anodes (DSA), ${ }^{7,12,13}$ and activated carbon fiber (ACF). ${ }^{14,15}$

In addition to the electrode materials, the efficiency of the electrochemical oxidation of organics is also dependent on the presence of species that can act as a mediator or oxidant in the bulk solution. The effect of chloride ions in the electrochemical oxidation of dyes and textile industry effluents has been the object of numerous studies. ${ }^{8,9,16}$ The oxidation of chloride ions produced from the addition of sodium chloride as a supporting electrolyte can lead to the formation of active oxidants such as chlorine, hypochlorous acid, and/or hypochlorite, depending on the $\mathrm{pH}$ (Eq. 1-3). These active oxidants can oxidize the organics at the anode or/and in the bulk solution (Eq. 4).

$$
\begin{aligned}
& 2 \mathrm{Cl}^{-} \rightarrow \mathrm{Cl}_{2}+2 \mathrm{e}^{-} \\
& \mathrm{Cl}_{2}+\mathrm{H}_{2} \mathrm{O} \rightarrow \mathrm{HOCl}+\mathrm{H}^{+}+\mathrm{Cl}^{-} \\
& \mathrm{HOCl} \rightarrow \mathrm{H}^{+}+\mathrm{OCl}^{-} \\
& \text {Organics }+\mathrm{OCl}^{-} \rightarrow \text { intermediates } \rightarrow \mathrm{CO}_{2} \\
& +\mathrm{Cl}^{-}+\mathrm{H}_{2} \mathrm{O}
\end{aligned}
$$

In the current study, the electrochemical oxidation of C. I. Reactive Orange 4 (RO4) and textile effluents were carried out using silver-carbon composite (AgC-PVC) electrode. The composite electrode was prepared by mixing two different element powders with polyvinyl chloride (PVC). The existence of two different elements in an electrode will give the synergistic effect ${ }^{17,18,19}$ and active bifunctional catalyst ${ }^{20,21}$ which directly increasing the electrode performance in the electrochemical oxidation and catalytic reaction. As for now, no studies have been done for the treatment of textile effluents by using this electrode. The characterization of the electrolysis products of $\mathrm{RO} 4$ and textile effluents were also performed in this study.

\section{Experimental}

\section{1. Chemicals}

All the chemicals used were analytical grade without further purification. Silver $(\mathrm{Ag})$ powder with a purity

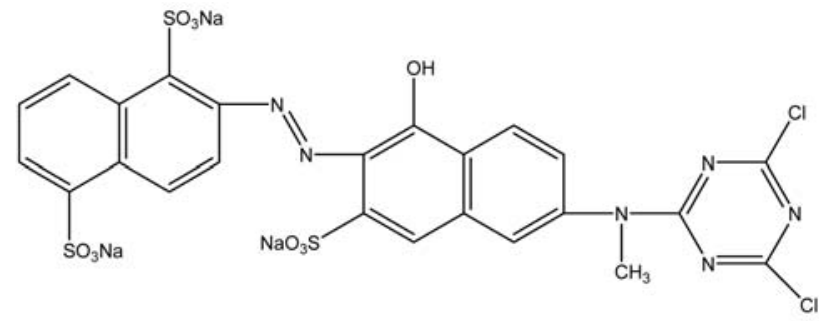

Figure 1. Molecular structure of RO4

of 99.9\% was purchased from Aldrich. RO4 (Figure 1), which was used as a synthetic dye in this study, was purchased from Dylon. Polyvinyl chloride (PVC) and graphite powder $(\mathrm{C})$ were obtained from BDH Ltd., whereas tetrahydrofuran (THF) was obtained from Systerm. Sodium chloride $(\mathrm{NaCl})$, which acted as a supporting electrolyte in the electrochemical reaction, was purchased from $\mathrm{R} \&$ M Chemicals. Dichloromethane (DCM) was purchased from Fischer Scientific.

\section{2. Preparation of AgC-PVC Electrode}

The AgC-PVC electrode was prepared using a mechanical alloying technique (MAT) ${ }^{22,23}$ by mixing the powder combination of $\mathrm{Ag}$ and $\mathrm{C}$ (Table 1) with PVC at a ratio of $95 \%$ powder mixture to $5 \%$ PVC (wt. \%). The total weight of the pellet obtained was approximately $1.5 \mathrm{~g}$. Then, $4 \mathrm{~mL}$ of THF was added to the mixture to dissolve the PVC. The mixture was then stirred until homogenous and allowed to dry in an oven $\left(100^{\circ} \mathrm{C}\right)$ for $2 \mathrm{~h}$. The mixture was placed in a $1-\mathrm{cm}$ diameter stainless steel mold and pressed at 10 toncm $^{-2}$. The pellet obtained was then connected to a silver wire with silver conducting paint (Sigma-Aldrich) and sealed in a glass rod. Subsequently, epoxy resin (Devcon) was applied to cover the silver wire connecting surface. The prepared AgC-PVC electrode was used for electrolysis cell and pilot-scale reactor.

\section{3. Electrochemical Measurement and Electrolysis of RO4}

Electrochemical measurements were performed us-

\begin{tabular}{|c|c|c|c|c|}
\hline Electrode & $\begin{array}{c}\text { Ag:C ratio } \\
(\%)\end{array}$ & $\begin{array}{c}\text { Mass of Ag } \\
\text { (g) }\end{array}$ & $\begin{array}{c}\text { Mass of C } \\
(\mathrm{g})\end{array}$ & $\begin{array}{c}\text { Mass of PVC } \\
\text { (g) }\end{array}$ \\
\hline$\overline{\mathrm{Ag}_{0.0} \mathrm{C}_{95,0}-\mathrm{PVC}_{5}}$ & $0: 100$ & - & 1.425 & 0.075 \\
\hline $\mathrm{Ag}_{28.5} \mathrm{C}_{66.5}-\mathrm{PVC}_{5}$ & $30: 70$ & 0.4275 & 0.9975 & 0.075 \\
\hline $\mathrm{Ag}_{47.5} \mathrm{C}_{47.5}-\mathrm{PVC}_{5}$ & $50: 50$ & 0.7125 & 0.7125 & 0.075 \\
\hline $\mathrm{Ag}_{66.5} \mathrm{C}_{28.5}-\mathrm{PVC}_{5}$ & $70: 30$ & 0.9975 & 0.4275 & 0.075 \\
\hline $\mathrm{Ag}_{95.0} \mathrm{C}_{0.0}-\mathrm{PVC}_{5}$ & 100:0 & 1.425 & - & 0.075 \\
\hline
\end{tabular}
ing a Radiometer Analytical Voltalab potentiostat (Model PGZ 402), whereas data acquisition was accomplished using the VoltaMaster 4 software. Cyclic voltammetry and

Table 1. Composition ratio and mass of Ag, C and PVC for the preparation of AgC-PVC electrodes 
linear potential measurements were carried out in a threeelectrode system, which consisted of working (AgC$\mathrm{PVC}$ ), counter ( $\mathrm{Pt}$ wire), and reference electrodes (saturated calomel electrode, $\mathrm{SCE}$ ). A $\mathrm{NaCl}$ solution was used as a supporting electrolyte. An electrolysis study was performed using a two-electrode system, which consisted of a working electrode (AgC-PVC electrode) and counter electrode (Pt plate), with a $\mathrm{NaCl}$ solution as a supporting electrolyte. A DC power supply (TTi PSU Bench CPX 400) was used throughout the electrolysis process. The electrochemical cell used for both experiments was a simple and undivided cell with a capacity of $100 \mathrm{~mL}$. Prior to any measurements, the solutions were deoxygenated by bubbling $\mathrm{N}_{2}$ gas through the solution for $15 \mathrm{~min}$, which was then allowed to flow freely throughout the entire experiment to remove the interfering oxygen gas during measurements.

\section{4. Instrumentation}

To observe the level of decolorization of the $\mathrm{RO} 4$ and effluents before and after treatment, the sample solution was characterized using an UV-Vis (Shimadzu UV2450) in the range of 200-900 $\mathrm{nm}$ using $10 \mathrm{~mm}$ quartz cuvettes. The electrolysis product was characterized using FTIR (Perkin Elmer 1310) in the range of 4000-400 $\mathrm{cm}^{-1}$ and GC-MS (Shimadzu QP5050A). The samples were extracted with DCM (HPLC grade) using separatory funnel liquid-liquid extraction method as described by Rajkumar et al (2007). ${ }^{13}$ The operating conditions of GC-MS is provided in Table 2. The Ag concentration in the aqueous solution was measured using ICP-OES (Perkin Elmer Optima 4300DV) using 6 series of standard solutions $(0.1,0.3,0.5,1.0,2.0$ and $5.0 \mathrm{ppm})$ as the calibration method.

Table 2. The operating conditions of GC-MS for the identification of intermediate compounds

\begin{tabular}{ll}
\hline GC Instrument & Shimadzu QP5050A \\
Injection mode & Split \\
Column & $\mathrm{HP}-5 \mathrm{MS}$ \\
Injection volume & $1 \mathrm{~mL}$ \\
Carrier gas/Flow & $\mathrm{N}_{2} / 1.1 \mathrm{~mL} \mathrm{~min}-1$ \\
Temperature program & $40{ }^{\circ} \mathrm{C}(10 \mathrm{~min}), 100{ }^{\circ} \mathrm{C}\left(12{ }^{\circ} \mathrm{C} / \mathrm{min}\right)$, \\
& $200{ }^{\circ} \mathrm{C}\left(5^{\circ} \mathrm{C} / \mathrm{min}\right), 270^{\circ} \mathrm{C}\left(20^{\circ} \mathrm{C} / \mathrm{min}\right)$ \\
Injector temperature & $240{ }^{\circ} \mathrm{C}$ \\
\hline
\end{tabular}

\section{5. Electrochemical Oxidation of Textile Effluents Using $\mathrm{Ag}_{28.5} \mathrm{C}_{66.5}-\mathrm{PVC}_{5}$ Electrode}

A sample was obtained from the batik industry in Terengganu, Malaysia. A pilot-scale reactor (Figure 2) with a 10-L capacity was equipped with four $\mathrm{Ag}_{28.5} \mathrm{C}_{66.5^{-}}$
$\mathrm{PVC}_{5}(30 \% \mathrm{Ag}: 70 \% \mathrm{C}$ ) electrodes (same dimension as stated in Section 2.2) as anodes and four stainless steel electrodes (20 cm long with $1.3 \mathrm{~cm}$ diameter) as cathodes. The distance between the electrodes was $3 \mathrm{~cm}$. A small water pump was used to circulate the effluent during electrolysis. Before electrolysis, the untreated textile effluents were characterized to determine the COD, $\mathrm{BOD}_{5}$, TSS, surfactant contents, and $\mathrm{pH}$. Standard methods 209C, 507, and 508B (Ref. ${ }^{24}$ ) were used for the TSS, $\mathrm{BOD}_{5}$ and COD analyses, respectively, whereas the surfactant was analyzed using the method described by Roslan et al (2010). ${ }^{25}$

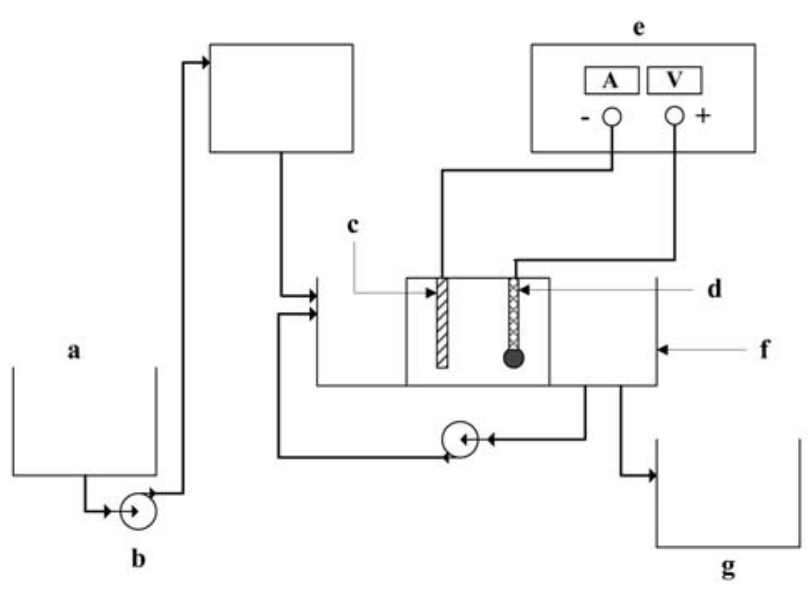

Figure 2. Schematic of pilot-scale reactor for electrochemical oxidation of textile effluents: (a) untreated effluent, (b) peristaltic pump, (c) stainless steel rod, (d) $\mathrm{Ag}_{28.5} \mathrm{C}_{66.5}-\mathrm{PVC}_{5}$ electrode, (e) potentiostat, (f) electrolysis cell, and (g) treated effluent. Total volume of effluent $=5 \mathrm{~L}$.

\section{Results and Discussion}

\section{1. Electrochemical Kinetic Parameter of Electrodes}

Previous studies showed that a Tafel plot is a good method for determining the speed of an electrochemical reaction. A Tafel plot can be used to verify the quality of an electrode, based on the previous studies conducted by Tapan et al. (2005). ${ }^{26}$ Figure 3 shows the Tafel plots for AgC-PVC electrodes with different Ag:C composition ratios $(0: 100,30: 70,50: 50,70: 30$, and 100:0) in a Tafel area of $+0.1 \mathrm{~V}$ to $+0.2 \mathrm{~V}$ (vs. SCE). The AgC-PVC electrode with a composition ratio of 30:70 (known as the $\mathrm{Ag}_{28.5} \mathrm{C}_{66.5}-\mathrm{PVC}_{5}$ electrode) exhibits the highest value of exchange current density $\left(i_{\mathrm{o}}\right)$, which is $3.555 \mathrm{~mA} \mathrm{~cm}$ (Table 3), compared to other electrodes. This shows that this electrode possesses better electrochemical catalytic properties. Therefore, the $\mathrm{Ag}_{28.5} \mathrm{C}_{66.5}-\mathrm{PVC}_{5}$ electrode was selected for further study on the decolorization of the RO4 solution. 
Table 3.Electrochemical kinetic parameters for AgC-PVC electrodes with different composition ratios in $4 \mathrm{mg} \mathrm{L}-1$ of $\mathrm{RO} 4+1.0 \mathrm{~mol} \mathrm{~L}-1 \mathrm{NaCl}$

\begin{tabular}{|c|c|c|c|c|}
\hline Electrode & $\mathbf{R}^{2}$ & $\begin{array}{c}\text { Tafel slope, } \\
\text { b }\left(\mathrm{mV} \mathrm{dec}^{-1}\right)\end{array}$ & $\begin{array}{l}\text { Reaction rate } \\
\text { constant, a }\end{array}$ & $\begin{array}{c}\text { Exchange current } \\
\text { density, } i_{0}\left(\mathrm{~mA} \mathrm{~cm} \mathrm{~cm}^{-2}\right)\end{array}$ \\
\hline $\mathrm{Ag}_{0.0} \mathrm{C}_{95.0}-\mathrm{PVC}_{5}$ & 0.948 & 319 & 1.175 & 0.207 \\
\hline $\mathrm{Ag}_{28.5} \mathrm{C}_{66.5}-\mathrm{PVC}_{5}$ & 0.985 & 354 & 0.867 & 3.555 \\
\hline $\mathrm{Ag}_{47.5} \mathrm{C}_{47.5}-\mathrm{PVC}_{5}$ & 0.987 & 344 & 0.885 & 2.675 \\
\hline $\mathrm{Ag}_{66.5} \mathrm{C}_{28.5}-\mathrm{PVC}_{5}$ & 0.990 & 243 & 0.788 & 0.572 \\
\hline $\mathrm{Ag}_{95.0} \mathrm{C}_{0.0}-\mathrm{PVC}_{5}$ & 0.982 & 259 & 0.815 & 0.713 \\
\hline
\end{tabular}

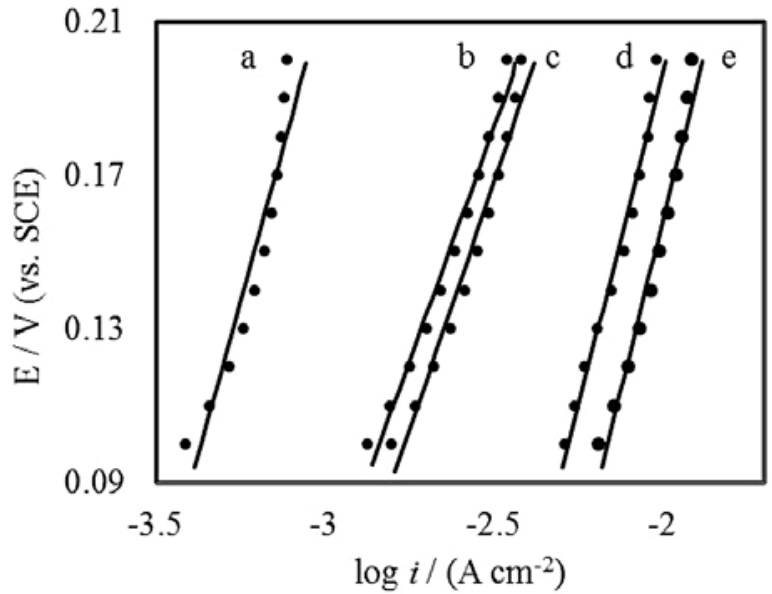

Figure 3. Tafel plots of (a) $\mathrm{Ag}_{0.0} \mathrm{C}_{95.0}-\mathrm{PVC}_{5}$, (b) $\mathrm{Ag}_{66.5} \mathrm{C}_{28.5}-\mathrm{PVC}_{5}$, (c) $\mathrm{Ag}_{95.0} \mathrm{C}_{0.0}-\mathrm{PVC}_{5}$, (d) $\mathrm{Ag}_{47.5} \mathrm{C}_{47.5}-\mathrm{PVC}_{5}$, and (e) $\mathrm{Ag}_{28.5} \mathrm{C}_{66.5}-\mathrm{PVC}_{5}$ in $4 \mathrm{mg} \mathrm{L}^{-1}$ of $\mathrm{RO} 4+1.0 \mathrm{~mol} \mathrm{~L}^{-1} \mathrm{NaCl}$ (scan rate $=1 \mathrm{mV} \mathrm{s}^{-1}$ )

\section{2. Cyclic Voltammetry of $\mathrm{Ag}_{28.5} \mathrm{C}_{66.5}-\mathrm{PVC}_{5}$ Electrode}

Cyclic voltammograms of the $\mathrm{Ag}_{28.5} \mathrm{C}_{66.5}-\mathrm{PVC}_{5}$ electrode in $1.0 \mathrm{~mol} \mathrm{~L}^{-1} \mathrm{NaCl}$ and $\mathrm{RO} 4$ are shown in Figure 4. Curve (a) (Figure 4) is the cyclic voltammogram for the electrolyte background. In the anodic potential sweep for curve (a), an anodic peak appeared at $+0.46 \mathrm{~V}$ (vs.

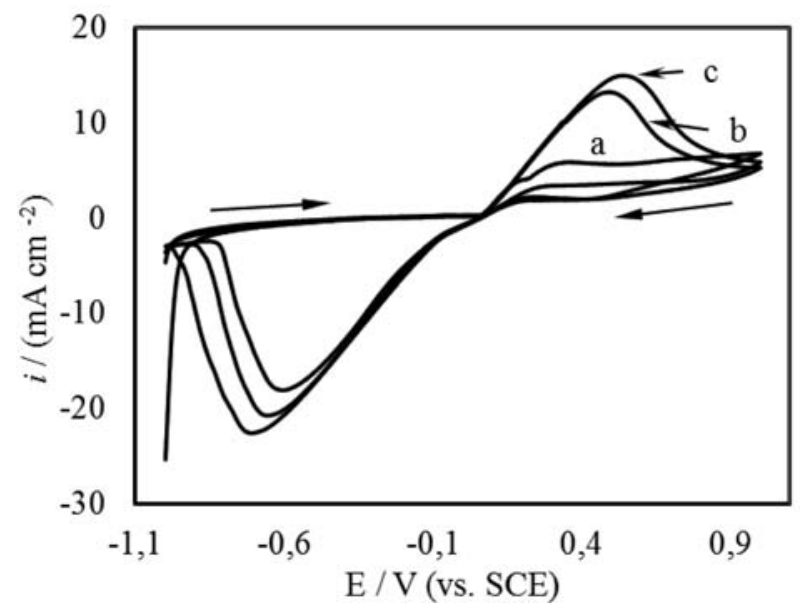

Figure 4. Cyclic voltammogram of (a) $1.0 \mathrm{~mol} \mathrm{~L}^{-1} \mathrm{NaCl}$; (b) 1.0 $\mathrm{mol} \mathrm{L}-1 \mathrm{NaCl}+4 \mathrm{mg} \mathrm{L}^{-1} \mathrm{RO} 4$; (c) $1.0 \mathrm{~mol} \mathrm{~L}^{-1} \mathrm{NaCl}+12 \mathrm{mg} \mathrm{L}^{-1}$ $\mathrm{RO} 4$ using $\mathrm{Ag}_{28.5} \mathrm{C}_{66.5}-\mathrm{PVC}_{5}$ electrode (scan rate $=100 \mathrm{mV} \mathrm{s}^{-1}$ )
SCE) while cathodic peak appeared at -0.67 (vs. SCE) due to the redox behavior of Ag. After the addition of the $\mathrm{RO} 4$ solution, the $\mathrm{Ag}_{28.5} \mathrm{C}_{66.5}-\mathrm{PVC}_{5}$ electrode exhibited an anodic peak at $+0.5 \mathrm{~V}$ (vs. SCE), whereas during a reverse scan, a cathodic peak appeared at $-0.65 \mathrm{~V}$ (vs. SCE). These anodic and cathodic peaks were both due to the redox behavior of $\mathrm{Ag}$ and $\mathrm{RO} 4$. The current density increased significantly with a further addition of RO4 (curve $b$ and c). This suggests that the electrochemical oxidation of RO4 is favorable in these media.

\section{3. Effect of Operating Parameters in Electrolysis}

Figure 5a shows that the decolorization efficiencies were significantly affected by the applied cell voltage. The satisfaction level for the decolorization when using a lower applied voltage should be considered because the application of a higher voltage in decolorization leads to energy loss, high temperatures, and electrode damage. ${ }^{27}$ Increasing the applied voltage from $4 \mathrm{~V}$ to $10 \mathrm{~V}$ increased the percentage of RO4 decolorization from $91.05 \%$ to $99.12 \%$ after $100 \mathrm{~min}$ of electrolysis. This was due to the increased generation of $\mathrm{OCl}^{-}$species. Figure $5 \mathrm{~b}$ shows that increasing the electrolysis time increased the decolorization level for RO4. A longer electrolysis time increased the generation of $\mathrm{OCl}^{-}$ions, which resulted in a better RO4 decolorization efficiency compared to a shorter electrolysis time. The figure shows that increasing the electrolysis time from $20 \mathrm{~min}$ to $100 \mathrm{~min}$ increased the level of decolorization from $84.85 \%$ to $99.12 \%$, respectively.

Figure $5 \mathrm{c}$ shows the effect of the supporting electrolyte concentration on the decolorization of the $\mathrm{RO} 4$ solution. The supporting electrolyte that was used in this study was a $\mathrm{NaCl}$ solution. The purpose of the $\mathrm{NaCl}$ addition during electrolysis was to modify the conductivity of the electrochemical process and facilitate the passage of the electrical current. The solution conductivity in the electrolytic cell influences the cell voltage, current efficiency, and electrical energy consumption. ${ }^{28}$ As seen in Figure $5 \mathrm{c}$, increasing the concentration of $\mathrm{NaCl}$ from 0.05 mol L ${ }^{-1}$ to $1.0 \mathrm{~mol} \mathrm{~L}^{-1}$ increased the level of RO4 decolorization after $100 \mathrm{~min}$ of electrolysis from $85.69 \%$ to $99.12 \%$, respectively. The generation of self-electrogenerated $\mathrm{OCl}^{-}$ions and the cell conductivity increased pro- 

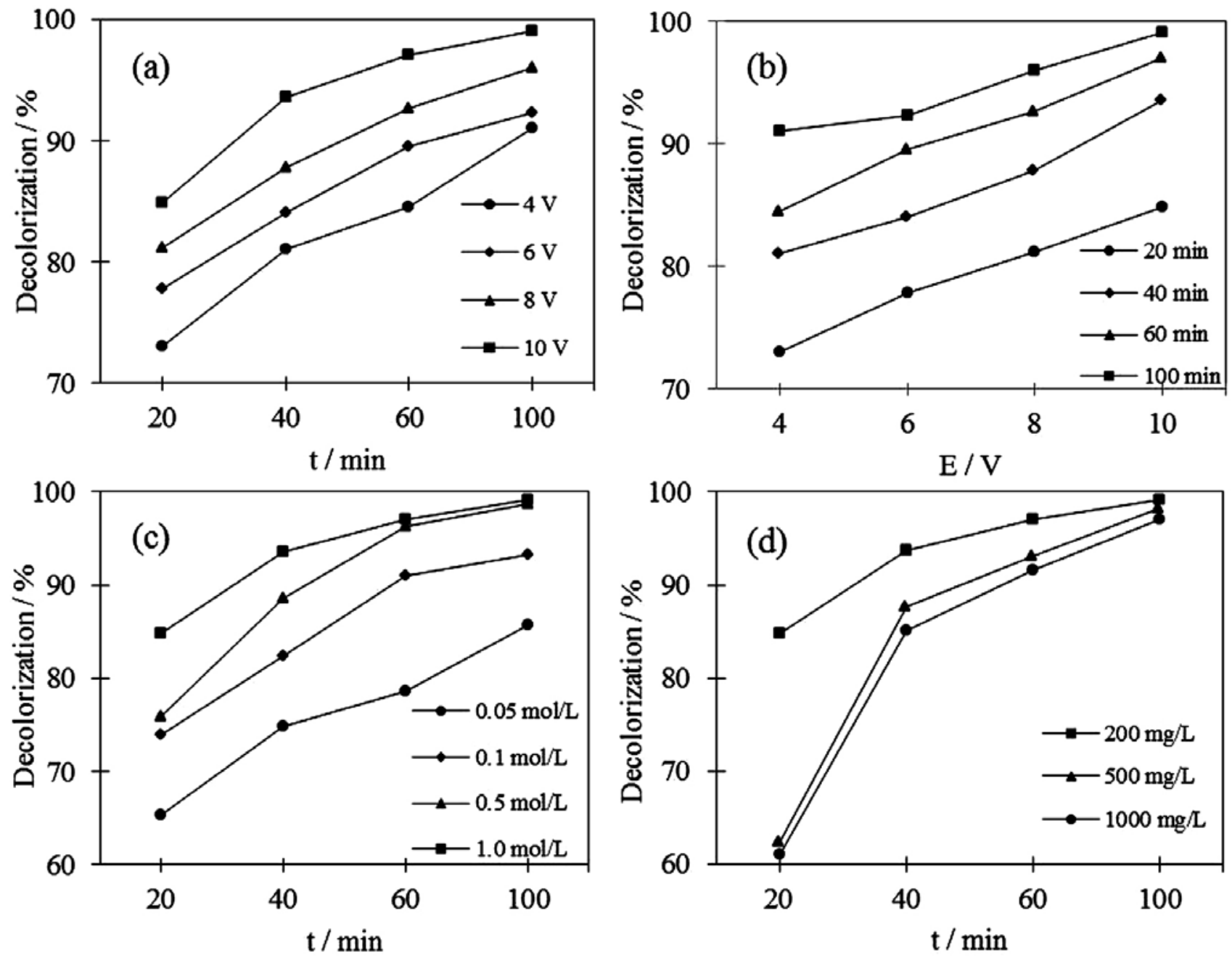

Figure 5. Effects of (a) applied voltage, (b) electrolysis time, (c) concentration of supporting electrolyte, and (d) initial concentration of RO4 on decolorization of RO4 solution

portionally with the concentration of the supporting electrolyte used. ${ }^{16}$ Figure $5 \mathrm{~d}$ shows that the initial concentration of dye played an important role in obtaining a satisfactory level of decolorization. As shown in this figure, the percentage of decolorization decreased from $99.12 \%$ to $96.99 \%$ when the initial concentration of the dye increased. This was explained by the decrease in the ratio of the $\mathrm{OCl}^{-}$species to the dye concentration with an increase in the initial dye concentration.

\section{4. Decolorization of RO4 Solution}

A UV-Vis spectrophotometer was used to determine the level of RO4 decolorization using the $\mathrm{Ag}_{28.5} \mathrm{C}_{66.5}$ $\mathrm{PVC}_{5}$ electrode before and after $100 \mathrm{~min}$ of electrolysis. Figure 6 shows the UV-Vis spectra obtained for $200 \mathrm{mg}$ $\mathrm{L}^{-1}$ of $\mathrm{RO} 4$ in $1.0 \mathrm{~mol} \mathrm{~L}^{-1} \mathrm{NaCl}$. The initial spectra ( $\left.0 \mathrm{~min}\right)$ showed that the wavelength of maximum absorbance $\left(\lambda_{\max }\right)$ at $391 \mathrm{~nm}$ in the $\mathrm{UV}$ region corresponded to the azo

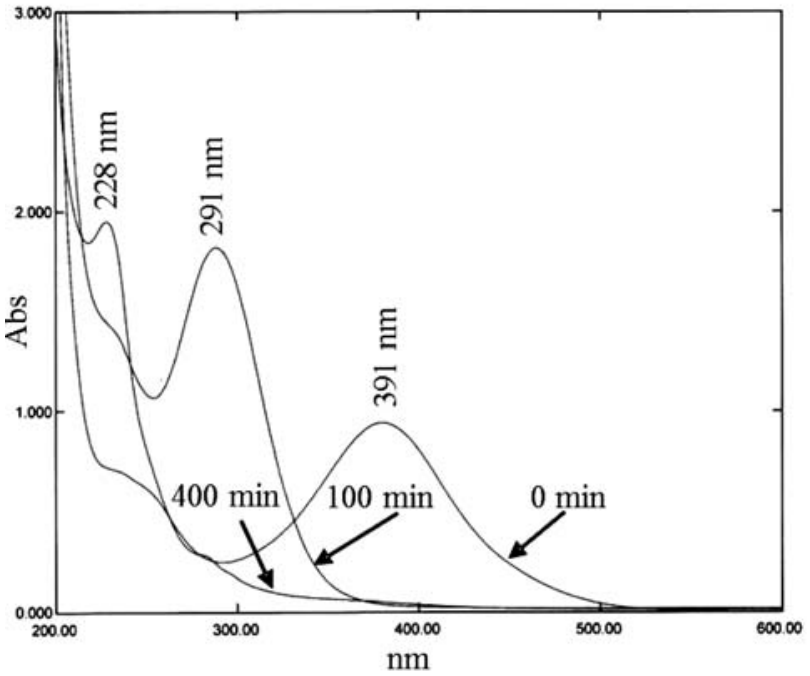

Figure 6. UV-Vis spectra of RO4 solution $\left([\mathrm{RO} 4]_{\mathrm{o}}=200 \mathrm{mg} \mathrm{L}^{-1}\right.$; $[\mathrm{NaCl}]=1.0 \mathrm{~mol} \mathrm{~L}^{-1} ; \mathrm{E}=10 \mathrm{~V}$ ) 
group. ${ }^{16}$ In addition, another peak was also observed at 228 $\mathrm{nm}$ in the UV region, which corresponded to conjugated aromatic rings. ${ }^{4}$ The spectra obtained after 100 min of electrolysis show the disappearance of the azo group and aromatic ring peaks after the electrolysis process. This suggest that the azo group and conjugated aromatic ring were completely destroyed by the electrochemical process, and a colorless solution was produced by the electrolysis.

The spectra obtained after 100 min of electrolysis also show the presence of a new peak at $291 \mathrm{~nm}$ in the UV region. This peak may not be related to an intermediate formation but correspond to the formation of an electrogenerated $\mathrm{OCl}^{-}$species, which is a powerful oxidant for the oxidation of organic pollutants. ${ }^{3}$ The electrolysis mechanism is shown below:

$$
\begin{aligned}
& \text { Anode: } 2 \mathrm{Cl}^{-} \rightarrow \mathrm{Cl}_{2}+2 \mathrm{e}^{-} \\
& \text {Cathode: } 2 \mathrm{e}^{-}+2 \mathrm{H}_{2} \mathrm{O} \rightarrow 2 \mathrm{HO}^{-}+\mathrm{H}_{2} \\
& \text { Overall: } 2 \mathrm{HO}^{-}+\mathrm{Cl}_{2} \rightarrow \mathrm{Cl}^{-}+\mathrm{OCl}^{-}+2 \mathrm{H}_{2} \mathrm{O}
\end{aligned}
$$

The presence of the peak at $291 \mathrm{~nm}$ at the end of the electrolysis shows that the mineralization of the dye was not completely achieved. ${ }^{8}$ Therefore, the complete mineralization of an organic compound must be ensured to prevent the formation of $\mathrm{OCl}^{-}$ions by extending the electrolysis time. ${ }^{29}$ Figure 6 shows the spectra obtained after $400 \mathrm{~min}$ of electrolysis. As can be seen, the $\mathrm{OCl}^{-}$ion formation peak at $291 \mathrm{~nm}$ completely disappeared.

\section{5. Characterization of Electrolysis Products}

\section{4. 1. FTIR Study}

Figure 7 shows the IR spectra of RO4 before and after the electrolysis process. It can be seen that some structural changes might have occurred during the electrolysis process. In Figure 7 for RO4 spectrum before the electrolysis process, the appearance of peaks at $3442.20 \mathrm{~cm}^{-1}$ and $1640.57 \mathrm{~cm}^{-1}$ indicates the presence of hydroxyl and azo groups, respectively. Additional peaks can also be noticed at $1553.87 \mathrm{~cm}^{-1}$ (secondary amine $\mathrm{N}-\mathrm{H}$ bend), $1478.90 \mathrm{~cm}^{-1}$ (aromatic $-\mathrm{C}=\mathrm{C}$ - stretching), $1346.83 \mathrm{~cm}^{-1}$ (triazinic group -C-N- stretching), and $1185.34 \mathrm{~cm}^{-1}$ (secondary amine $\mathrm{C}-\mathrm{N}$ stretching). The other peaks at $1026.55 \mathrm{~cm}^{-1}, 848.63 \mathrm{~cm}^{-1}$, and $626.35 \mathrm{~cm}^{-1}$ are thought to belong to $\mathrm{C}-\mathrm{O}-\mathrm{H}$, aromatic $\mathrm{C}-\mathrm{H}$, and $\mathrm{C}-\mathrm{Cl}$ stretching, respectively. The IR spectra of $\mathrm{RO} 4$ after the electrolysis process (Figure 7) show the appearance of peaks at around $3428.79 \mathrm{~cm}^{-1}$ and $1644.85 \mathrm{~cm}^{-1}$, which correspond to the hydroxyl and carbonyl groups, respectively. This variation in the IR spectra could be related with the aromatic rings breakage leading to the accumulation of low molecular weight species with hydroxyl and carbonyl groups.

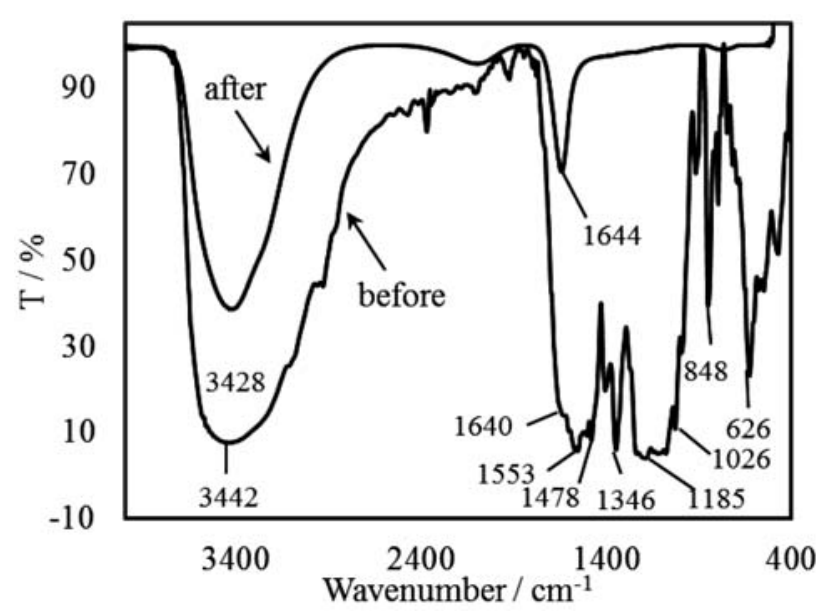

Figure 7. IR spectra of RO4 solution before and after electrolysis of RO4

\section{4. 2. GC-MS Study}

The intermediate compounds formed during the degradation of RO4 were identified using GC-MS. Samples were collected at different time intervals during the electrolysis of $200 \mathrm{mg} \mathrm{L}^{-1}$ of RO4. Figure 8 shows the proposed mechanism for the electrochemical oxidation of RO4. The retention time for all of the intermediate compounds formed was summarized in Table 4. The 20-min electrolysis results illustrated in Figure 8 shows the formation of compounds (i) to (vi) while the compounds identified after $100 \mathrm{~min}$ of electrolysis is compound (iii) and (vii), as showed in Table 4. Compound (iii) is present in the sam-

\begin{tabular}{|c|c|c|c|c|}
\hline No. & Compound name & Molecular weight $\left(\mathrm{g} \mathrm{mol}^{-1}\right)$ & Molecular formula & Retention time (min) \\
\hline (i) & (2-(pentyloxy)ethyl)cyclohexane & 198.34 & $\mathrm{C}_{13} \mathrm{H}_{26} \mathrm{O}$ & 14.91 \\
\hline (ii) & 2-methyl benzoic acid & 136.15 & $\mathrm{C}_{8} \mathrm{H}_{8} \mathrm{O}_{2}$ & 47.03 \\
\hline (iii) & 1,3-dichlorocyclopentane & 139.02 & $\mathrm{C}_{5} \mathrm{H}_{8} \mathrm{Cl}_{2}$ & 5.60 \\
\hline (iv) & 1,2-dichlorocyclohexane & 153.05 & $\mathrm{C}_{6} \mathrm{H}_{10}{ }_{10} \mathrm{Cl}_{2}$ & 10.63 \\
\hline (v) & 1-chloro-2-(2-chloroethoxy)ethane & 143.01 & $\mathrm{C}_{4} \mathrm{H}_{8} \mathrm{Cl}_{2} \mathrm{O}$ & 7.40 \\
\hline (vi) & methyl-2,3-dichlorobutanoate & 171.02 & $\mathrm{C}_{5} \mathrm{H}_{8} \mathrm{Cl}_{2} \mathrm{O}_{2}$ & 9.96 \\
\hline (vii) & methyl 2,2,3-trichlorobutanoate & 205.47 & $\mathrm{C}_{5} \mathrm{H}_{7} \mathrm{Cl}_{3} \mathrm{O}_{2}$ & 16.19 \\
\hline
\end{tabular}
ples at different time intervals. This suggest that this com-

Table 4. Retention time for intermediate compounds formed by GC-MS 
<smiles>CCOc1cc2cc(N(C)c3nc(Cl)nc(Cl)n3)ccc2c(O)c1N=Nc1ccc2c([N+](=O)[O-])cccc2c1S(C)(=O)=O</smiles><smiles>CCCCCOCCC1CCCCC1</smiles>

(i)<smiles>ClCCOCCCl</smiles>

(iv)

(v)<smiles>Cc1ccccc1C(=O)O</smiles>

(ii)

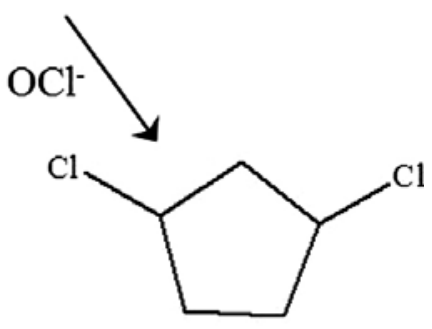

(iii)<smiles>CCCCC(C)Cl</smiles>

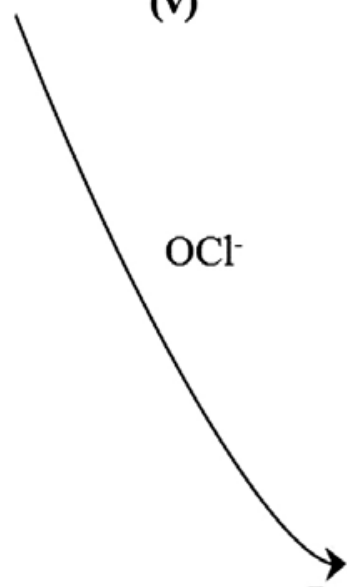<smiles>COC(=O)C(Cl)(C(C)Cl)C(C)Cl</smiles>

(vii)

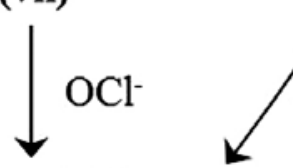

$\mathrm{OCl}^{-}$

Low molecular weight compounds

Figure 8. Proposed mechanism for electrochemical oxidation of RO4

pound was formed over the period of the electrolysis process.

The presence of an active oxidant during electrolysis causes the RO4 molecules to be broken down into several small molecules. The active oxidant will continue to break down the molecules that have been formed into other molecules with lower molecular masses at the end of the electrolysis process. Several compounds showed the presence of carbonyl groups in their molecular structures. This may support the results obtained from the FTIR study (Figure 7), where the figure shows the appearance of the carbonyl group in the molecular structure of $\mathrm{RO} 4$ after 100 min of electrolysis.

Most of the compounds produced during the electrolysis of RO4 were undesirable toxic and mutagenic chlorinated by-products. They were produced by the 
presence of chloride ions in the solution. ${ }^{4,6}$ This is the main disadvantage of using the electrochemical oxidation technique in the presence of chloride ions. However, the generation of chlorinated by-products can be controlled by two things: (1) the concentration of $\mathrm{NaCl}$ (a greater $\mathrm{NaCl}$ concentration will result in greater chlorinated by-product generation) and (2) the current density (low current densities produce fewer chlorinated by-products). ${ }^{6}$

\section{6. Stability Analysis of $\mathrm{Ag}_{28.5} \mathrm{C}_{66.5}-\mathrm{PVC}_{5}$ Electrodes}

The stability of the prepared electrode was determined by cyclic voltammogram with five cycles as shown in Figure 9. The anodic (A1) and cathodic (C1) peaks shift towards positive and negative potential, respectively in $\mathrm{Fi}$ gure 9 is not really significant between each cycle. It shows better stability of the electrode in the electrochemical oxidation of RO4. The stability of $\mathrm{Ag}$ in the $\mathrm{Ag}_{28.5} \mathrm{C}_{66.5}-\mathrm{PVC}_{5}$ electrode after the electrolysis of 200 $\mathrm{mg} \mathrm{L}^{-1}$ of RO4 was determined using ICP-OES. The result obtained is summarized in Table 5. As can be seen, the percentage of $\mathrm{Ag}$ ions in an electrolytic solution was very insignificant, which indicated that the electrodes used were very stable because of the low amount of dissolved Ag in the solution.

\section{7. Surface Morphology of $\mathrm{Ag}_{28.5} \mathrm{C}_{66.5}-\mathrm{PVC}_{5}$ Electrodes}

Figure 10 shows the FESEM micrograph obtained from the morphological study of freshly prepared $\mathrm{Ag}_{28.5} \mathrm{C}_{66.5}-\mathrm{PVC}_{5}$ (a) and after (b) electrolysis of $200 \mathrm{mg}$ $\mathrm{L}^{-1} \mathrm{RO} 4$ using $10 \mathrm{~V}$ applied voltage and $100 \mathrm{~min}$ elec- trolysis. The FESEM micrograph in Figure 10a shows that the surface of the electrode was rough and irregular. In addition, the surface of the prepared electrode shows that the existence of voids that are not filled by the element and PVC. The voids formed normally will increase the porosity characteristic of the electrode which allowing electrochemical oxidation occurred within the electrode.

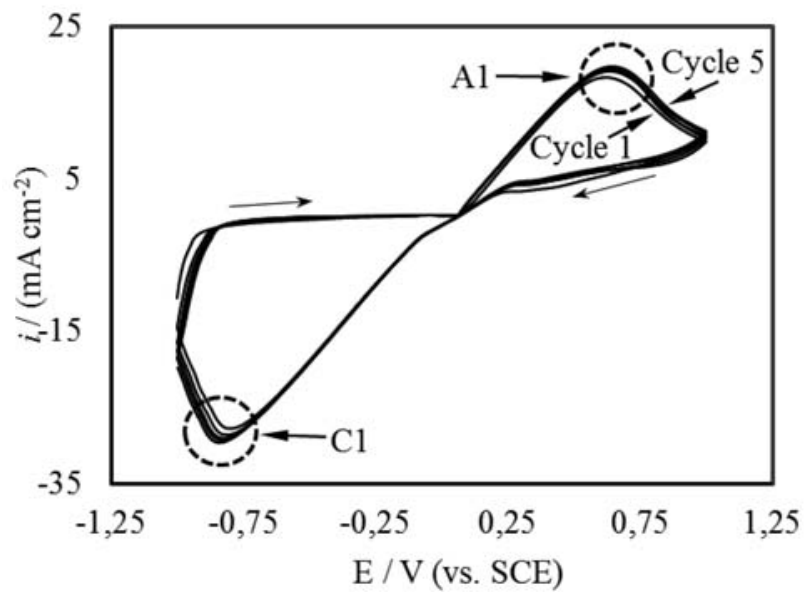

Figure 9. Cyclic voltammogram of $\mathrm{Ag}_{285} \mathrm{C}_{66}-\mathrm{PVC}_{5}$ electrode in 4 $\mathrm{mg} \mathrm{L}^{-1}$ of $\mathrm{RO} 4+0.1 \mathrm{~mol} \mathrm{~L}^{-1} \mathrm{NaCl}$ with five cycles (scan rate $=100$ $\mathrm{mV} \mathrm{s}^{-1}$ )

Table 5. Percentage of dissolved Ag in electrolytic solution after electrolysis of $200 \mathrm{mg} \mathrm{L}^{-1}$ of $\mathrm{RO} 4$ in $1.0 \mathrm{~mol} \mathrm{~L}^{-1} \mathrm{NaCl}$ using $\mathrm{Ag}_{28.5} \mathrm{C}_{66.5}-\mathrm{PVC}_{5}$ electrode

\begin{tabular}{lc}
\hline Mass of Ag in electrode $(\mathrm{g})$ & 0.4275 \\
Concentration of $\mathbf{A g}$ in electrolytic & 164.9 \\
solution $\left(\boldsymbol{\mu g} \mathbf{~ L}^{-\mathbf{1}}\right)$ & \\
Percentage of dissolved $\mathbf{A g}(\%)$ & $1.32 \times 10^{-3}$ \\
\hline
\end{tabular}

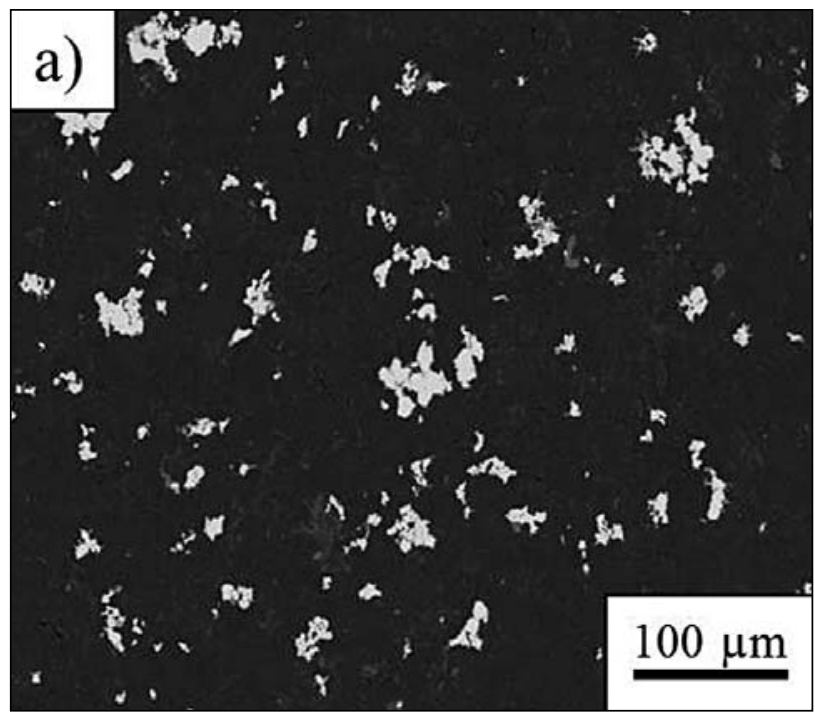

Figure 10. FESEM micrograph of freshly prepared $\mathrm{Ag}_{28.5} \mathrm{C}_{66.5}-\mathrm{PVC}_{5}$ electrode using a) 100x and b) 4000x magnifications. 


\section{8. Electrochemical Oxidation of Textile Effluents Using $\mathrm{Ag}_{28.5} \mathrm{C}_{66.5}-\mathrm{PVC}_{5}$ Electrode}

Figure 11 shows the UV-Vis spectra for textile effluents before and after treatment with an electrochemical technique using the pilot-scale reactor. For untreated effluents $(0 \mathrm{~min})$, two peaks are observed at wavelengths of 478 and $605 \mathrm{~nm}$. The appearance of the peak at $478 \mathrm{~nm}$ in the visible region corresponds to the azo group,$^{30}$ whereas the peak at $605 \mathrm{~nm}$ in the visible region corresponds to the anthraquinone group. ${ }^{13}$ After 100 min of electrolysis using the $\mathrm{Ag}_{28.5} \mathrm{C}_{66.5}-\mathrm{PVC}_{5}$ electrode with an applied voltage of $10 \mathrm{~V}$ in the presence of $1.0 \mathrm{~mol} \mathrm{~L}^{-1}$ of $\mathrm{NaCl}$ as a supporting electrolyte, the previous peaks completely disappeared, proving that the electrochemical oxidation method was able to decolorize all the colored material in the effluents.

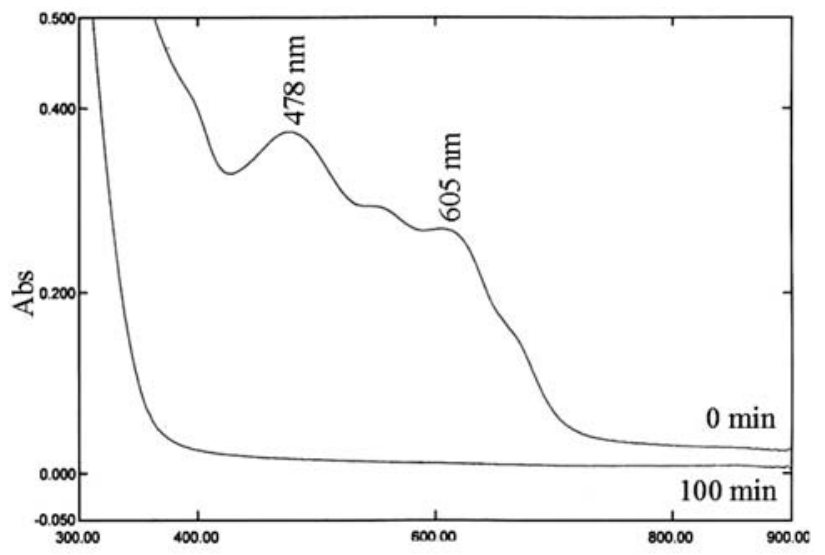

Figure 11. UV-Vis spectra for textile effluents before and after treatment using electrochemical oxidation technique $([\mathrm{NaCl}]=1.0$ mol L $\mathrm{L}^{-1}$, applied voltage $=10 \mathrm{~V}, \mathrm{t}=100 \mathrm{~min}$ )

\section{9. Characterization of Treated Textile Effluents}

Studies on untreated and treated textile effluents using various effluent parameters have been reported by many authors ${ }^{31-33}$ The characterization results for the textile effluents before and after treatment were summarized in Table 6. In addition to the color removal shown in Figure 11, the electrochemical method using the $\mathrm{Ag}_{28.5} \mathrm{C}_{66.5^{-}}$ $\mathrm{PVC}_{5}$ electrode could also significantly reduce the COD, $\mathrm{BOD}_{5}$, and surfactant content (Table 6). As previously discussed, textile effluents contain, not only colored compounds (e.g., azo compounds), but also numerous oxidizable organic compounds that cannot be oxidized by microorganisms. Therefore, treatment using this technique could not only significantly reduce the existing organic compounds, but could also reduce these compounds to much softer oxidizable organic compounds.
Table 6. Characterization of textile industrial effluents before and after treatment with electrochemical method using $\mathrm{Ag}_{28.5} \mathrm{C}_{66.5^{-}}$ $\mathrm{PVC}_{5}$ electrode (supporting electrolyte $=1.0 \mathrm{~mol} \mathrm{~L}^{-1} \mathrm{NaCl}$, applied voltage $=10 \mathrm{~V}, \mathrm{t}=100 \mathrm{~min}$, energy consumption $=2.86 \mathrm{kWh} \mathrm{g}^{-1}$ )

\begin{tabular}{lcc}
\hline Parameters & Before treatment & After treatment \\
\hline COD $\left(\mathrm{mg} \mathrm{L}^{-1}\right)$ & 1728.00 & 448.00 \\
$\mathrm{BOD}_{5}\left(\mathrm{mg} \mathrm{L}^{-1}\right)$ & 51.30 & 22.50 \\
$\mathrm{TSS}_{\left(\mathrm{m} \mathrm{L}^{-1}\right)}$ & 768.57 & 178.29 \\
Surfactant $\left(\mathrm{mg} \mathrm{L}^{-1}\right)$ & 25.16 & 14.49 \\
$\mathrm{pH}$ & 10.97 & 10.07 \\
\hline
\end{tabular}

\section{Conclusions}

$\mathrm{An} \mathrm{AgC}-\mathrm{PVC}$ electrode composed of $30 \% \mathrm{Ag}$ and $70 \% \mathrm{C}$ (known as the $\mathrm{Ag}_{28.5} \mathrm{C}_{66.5}-\mathrm{PVC}_{5}$ electrode) was found to be the best among the prepared electrode because it had the highest value of exchange current density $\left(i_{\mathrm{o}}\right)$, which is $3.555 \mathrm{~mA} \mathrm{~cm}^{-2}$. This high value of $i_{\mathrm{o}}$ showed that the electrode possessed better electrochemical catalytic properties. This electrode was applied to the decolorization of RO4 and textile effluents. The results showed that when the $\mathrm{Ag}_{28.5} \mathrm{C}_{66.5}-\mathrm{PVC}_{5}$ electrode was used with an applied voltage of $10 \mathrm{~V}$ in the presence of $1.0 \mathrm{~mol} \mathrm{~L}^{-1} \mathrm{NaCl}$ for 100 min of electrolysis to decolorize RO4 solution and textile effluent, decolorization percentages of more than 95\% were obtained for both RO4 and effluent solution. This electrode was also able to reduce the $\mathrm{COD}, \mathrm{BOD}_{5}$, and surfactant contents of a colored solution during the treatment of textile effluents using this electrochemical technique with a pilot treatment plant, which makes it viable at a larger scale.

\section{Acknowledgement}

The funding from Universiti Kebangsaan Malaysia through grants UKM-AP-2011-021, UKM-DLP-2012024, DIP-2012-22, and DPP-2013-058 are gratefully acknowledged. The funding from the Ministry of Science, Technology and Innovation of Malaysia (06-01-02SF0555) is also very much appreciated.

\section{References}

1. V. Lopez-Grimau, M. C. Gutierrez, Chemosphere 2006, 62, 106-112.

http://dx.doi.org/10.1016/j.chemosphere.2005.03.076

2. C. A. Martinez-Huitle, E. Brillas, Appl. Catal. B-Environ. 2009, 87, 105-145.

http://dx.doi.org/10.1016/j.apcatb.2008.09.017

3. A. Fernandes, A. Morao, M. Magrinho, A. Lopes, I. Goncalves, Dyes Pigments 2004, 61, 287-296.

http://dx.doi.org/10.1016/j.dyepig.2003.11.008

4. A. I. Del Rio, J. Molina, J. Bonastre, F. Cases, J. Hazard. 
Mater. 2009, 172, 187-195.

http://dx.doi.org/10.1016/j.jhazmat.2009.06.147

5. J. Bandara, P. T. Wansapura, S. P. B. Jayathilaka, Electrochim. Acta 2007, 52, 4161-4166. http://dx.doi.org/10.1016/j.electacta.2006.11.036

6. M. Riera-Torres, M. C. Gutierrez, Chem. Eng. J. 2010, 156, 114-120. http://dx.doi.org/10.1016/j.cej.2009.10.006

7. M. Ilhos, G. Bocea, A. Iovi, Chem. Bull. 2005, 50, 1-2.

8. S. Raghu, C. A. Basha, J. Hazard. Mater. 2007, 139, 381390. http://dx.doi.org/10.1016/j.jhazmat.2006.06.082

9. J. B. Parsa, M. Rezaei, A. R. Soleymani, J. Hazard. Mater. 2009, 168, 997-1003.

http://dx.doi.org/10.1016/j.jhazmat.2009.02.134

10. A. S. Koparal, Y. Yayuz, C. Gurel, U. B. Ogutveren, J. Hazard. Mater. 2007, 145, 100-108.

http://dx.doi.org/10.1016/j.jhazmat.2006.10.090

11. M. Panizza, G. Cerisola, J. Hazard. Mater. 2008, 153, 83-88. http://dx.doi.org/10.1016/j.jhazmat.2007.08.023

12. N. Mohan, N. Balasubramanian, C. A. Basha, J. Hazard. Mater. 2007, 147, 644-651.

http://dx.doi.org/10.1016/j.jhazmat.2007.01.063

13. D. Rajkumar, B. J. Song, J. G. Kim, Dyes Pigments 2007, 72, 1-7. http://dx.doi.org/10.1016/j.dyepig.2005.07.015

14. L. Fan, Y. Zhoub, W. Yang, G. Chen, F. Yang, J. Hazard. Mater. 2006, 137, 1182-1188.

http://dx.doi.org/10.1016/j.jhazmat.2006.04.008

15. F. Yi, S. Chen, C. Yuan, J. Hazard. Mater. 2008, 157, 79-87. http://dx.doi.org/10.1016/j.jhazmat.2007.12.093

16. A. Maljaei, M. Arami, N. M. Mahmoodi, Desalination 2009, 249, 1074-1078. http://dx.doi.org/10.1016/j.desal.2009.05.016

17. M. M. D. Jimenez, M. P. Elizalde, M. Gonzalez, R. Silva, Electrochim. Acta 2000, 45, 4183-4193.

18. I. H. Yeo, D. C. Johnson, J. Electroanal. Chem. 2001, 495, 110-119. http://dx.doi.org/10.1016/S0022-0728(00)00401-0

19. F. Bonet, S. Grugeon, L. Dupont, R. H. Urbina, C. Guery, J.
M. Tarascon, J. Solid State Chem. 2003, 172, 111-115. http://dx.doi.org/10.1016/S0022-4596(02)00163-9

20. P. Cox, D. Pletcher, J. Appl. Electrochem. 1990, 20, 549554. http://dx.doi.org/10.1007/BF01008862

21. M. G. Pereira, M. D. Jimenez, M. P. Elizalde, A. M. Robledo, N. A. Vante, Electrochem. Acta 2004, 49, 3917-3925. http://dx.doi.org/10.1016/j.electacta.2004.01.080

22. Riyanto, J. Salimon, M. R. Othman, 2007, 36, 175-181.

23. Riyanto, M. R. Othman, Open Mater. Sci. J. 2008, 2, 40-46. http://dx.doi.org/10.2174/1874088X00802010040

24. APHA, AWWA, WPCF, Standard Methods for the Examination of Water and Effluents, American Public Health Association, Washington DC, USA, 1981, 96-97, 525-532, 533-535.

25. R. N. Roslan, N. Mohd Hanif, M. R. Othman, W. N. F. Wan Azmi, X. Y. Xan, M. Mohd Ali, C. A. B. Mohamed, M. T. Latif, Mar. Pollut. Bull. 2010, 60, 1584-1590. http://dx.doi.org/10.1016/j.marpolbul.2010.04.004

26. N. A. Tapan, W. E. Mustain, J. Prakash, Proceedings International Hydrogen Energy Congress and Exhibition (IHEC), Istanbul, Italy, 2005.

27. A. Sakalis, K. Fytianos, U. Nickel, A. Voulgaropoulos, Chem. Eng. J. 2006, 119, 127-133. http://dx.doi.org/10.1016/j.cej.2006.02.009

28. I. A. Sengil, M. Ozacar, J. Hazard. Mater. 2009, 16, 13691376. http://dx.doi.org/10.1016/j.jhazmat.2008.04.100

29. N. Nordin, S. F. M. Amir, Riyanto, M. R. Othman, Int. J. Electrochem. Sci. 2013, 8, 11403-11415.

30. L. Xu, H. Zhou, S. Shi, G. Zhang, J. Ni, Dyes Pigments 2008, 77, 158-164. http://dx.doi.org/10.1016/j.dyepig.2007.04.004

31. J. B. Parsa, M. Abbasi, Acta Chim. Slov. 2007, 54, 792-796.

32. S. Raghu, C. W. Lee, S. Chellammal, S. Palanichamy, C. A. Basha, J. Hazard. Mater. 2009, 171, 748-754. http://dx.doi.org/10.1016/j.jhazmat.2009.06.063

33. D. Rajkumar, J. G. Kim, J. Hazard. Mater. 2006, 136, 203212. http://dx.doi.org/10.1016/j.jhazmat.2005.11.096

\section{Povzetek}

Proučevana je bila elektrokemijska oksidacija barvila reaktivno oranžno 4 (RO4) na elektrodi iz kompozitnega materiala srebro-ogljik (AgC-PVC). Omenjena elektroda je služila kot delovna elektroda za merjenje vsebnosto RO4 ob prisotnosti $\mathrm{NaCl}$ kot podpornega elektrolita. Po elektrokemijski oksidaciji je UV-Vis spekter pokazal popolno razbarvanje raztopine. Produkti elektrolize, ki so bili okarakterizirani s pomočjo FTIR in GCMS analize, so pokazali, da je molekula RO4 razpadla v manjše molekule ob prisotnosti $\mathrm{OCl}^{-}$kot aktivnega oksidanta. Uporabljena elektroda je zmanjšala tudi $\mathrm{KPK}, \mathrm{BPK}_{5}$ in vsebnost surfaktantov v odpadnih vodah iz tekstilne industrije v pilotnem reaktorju. Rezultati dokazujejo uporabnost proučevane AgC-PVC elektrode za razbarvanje in odstranjevanje drugih polutantov iz odpadnih voda tekstilne industrije. 